\title{
The collapse of the post-socialist industrial relations system in Hungary
}

\begin{abstract}
The post-socialist industrial relations system has practically collapsed in Hungary as a consequence of the deep and long economic, political and ethical crisis following the credit crunch, which begun in Hungary in summer 2006. One may argue that this collapse was preceded by a protracted weakening and decomposition of the main actors, especially the trade unions. This article, however, argues that the collapse was brought about by the political strategy of the government elected in 2010. The government has proceeded to destroy the post-socialist industrial relations system in order to remove a potential veto-point, a checking power on government actions, in the drive to re-organise the country. Moreover, the government also intends to nudge a new system, partially by supporting those actors close to it and partially by creating new institutions. The goal is that the new system would be the partner of the government in the re-organisation of the country and provide a kind of democratic legitimacy to government policies. We should note, however, that such efforts are also speeding up the decomposition of those actors preferred by the government.
\end{abstract}

Keywords: transition, post-socialism, industrial relations, interest representation, social dialogue, union pluralism, tripartism, labour law, declining legitimacy, political polarisation, austerity, crisis, neo-liberalism, union merger, state domination

Introduction

This article first describes the process of the foundation of the post-socialist industrial relations system in the early nineties and its slow decomposition. The second part portrays the polarisation of political life and its impact on industrial relations, while the third describes the destruction of the national industrial relations system which largely took place between 2010 and 2013 but which is still an ongoing process. Finally the paper summarises the direction of change and addresses the issue as to whether there is any chance of a renewal of an autonomous system of industrial relations.

The nature of the post-socialist industrial relations system

The system change in Hungary took place almost overnight. In a relatively short period, between 1989 and 1991, the key actors were formed and the essential institutions of the post-socialist industrial relations system were laid down, practically almost out of thin air. There were elements of path-dependency and institutional rigidity, combined with institutional borrowing (Stark and Bruszt, 1998), but a new institutional environment was formed and the actors were acting in novel ways. The ways of novel 
working were facilitated by the emergence of a new elite across society which also represented a generational change. This path-dependency, institutional borrowing and novel way of a new start characterised the creation of the new post-socialist industrial relations system.

Additionally, the transition ended, to a certain extent, with inconclusive results in the field of industrial relations. It was more or less clear to all those participating in the creation of the new system which part of the regulations and institutions needed to be repealed and reformed as incompatible with democracy, the rule of law and the market economy. Nevertheless, many of the new institutions and pieces of regulation were created during a contested process among key stakeholder actors, based both on a perception of what is necessary for a well-functioning market economy as well as on their perceived political, organisational and personal interests.

The key factor in the creation of the industrial relations system was that the transition period had been inconclusive as far as trade union renewal was concerned. New, non-communist unions had been established, following the example of the Polish Solidarność, but they were unable to attract more than a few thousand members or takeover the function of employee representation. The former communist unions did not collapse, and they were able to survive the transition and maintain much of their four million strong membership, organisational presence and wealth.

The consequence of this inconclusive period was that there developed a deeplydivided union structure, fractured along political lines. The new unions, Munkástanácsok and Liga, on the one hand, had political ties to the anti-communist pro-democratic parties, while the former communist reformed unions, MSZOSZ, Autonómok, SZEF and ÉSZT, on the other hand, were seen by the new political elite as remnants of the past which may lend organisational and political support to the reformed former communist party, the MSZP.

The newly-elected government of right-wing conservative parties, led by MDF, had the intention of building a new industrial relations system, following the example of the model of the German social market economy, which was intended to ensure institutional harmonisation with the concept of Social Europe. However, the government viewed unions with suspicion, partly as a result of the organisational dominance of the former-communist unions and their earlier role in collaborating with management at workplace level. In part, the weak new pro-democratic unions had been unable to develop a new legitimacy for the union movement as such among the new democratic forces which were trusted by voters to create the institutional framework for the new democracy. This suspicion, due to the management dominance of unions in socialist times, was shared by influential experts, government officials and judges alike (Kollonay and Ladó, 1996).

The consequence of this suspicion and lack of legitimacy on behalf of unions in the eyes of key government politicians, officials and experts had a major impact on how the new system was designed. The lack of a mass pro-democratic workers' movement meant that the new political elite did not have to take into account the demands of a legitimate and powerful union movement which knew what it wanted in order to be able effectively to represent the interests of members and thus ensure a strong organisational presence. 
The result was an imbalanced, top-heavy industrial relations system, with weak institutional and regulative underpinnings at sectoral and workplace level.

The new industrial relations system was top-heavy since the key institution of the new system was a standing statutory tripartite body for national level consultation over key global issues. The set up of a statutory tripartite body was recommended by the International Labour Organization and was seen as a key institutional anchor for social piece and European harmonisation (Héthy, 1995; Ladó, 1997). This move was supported by employer associations and trade unions alike (Bruszt, 1993). The government invited all existing self-proclaimed national level employer associations, nine altogether; and trade unions, which numbered six. ${ }^{1}$ All invited organisations, irrespective of their organisational strength, received one vote, and it was required to have unanimous voting on the side of the employer and trade unions when it came to voting. The national tripartite body was complemented by several tripartite bodies to oversee key policy areas related to the world of work.

Over the years, the tripartite body became an important venue for grand bargaining over key issues related to the world of work which, in most cases where issues were contested, was able to hammer out a compromise and give a certain legitimacy to government policies.

The creation of standing tripartite bodies ensured legitimacy, lobbying power and a bargaining table for the fifteen organisations invited, while it also stabilised their organisational existence and gave continuous access to political decision-makers. It further ensured media coverage and the ability to put pressure on the government through the media, irrespective of the shape of traditional industrial power. The government also provided financial support to the member organisations of the tripartite body. This financial support, with the dwindling of membership, became a key source of revenue for all employer associations and trade unions (Tóth, 2005). There developed a kind of state-sponsored national level machinery of social dialogue. As for the employer associations and trade unions, their legitimacy, lobbying power and even organisational existence increasingly depended on the existence and proper functioning of the tripartite body.

If the national tripartite body ensured legitimacy, lobbying power and resources for national level headquarters, the 1992 Labour Code questioned the legitimacy of trade unions to represent employees exclusively and to represent them without the prior approval of those they claimed to represent. Furthermore, this regulation stripped unions of some of their key traditional rights and entitlements, which would give them a legal underpinning for their bargaining function (Tóth, 1997a).

At workplace level, the institution of works councils was established to complement local unions, and many of the rights of unions to be consulted and informed were transferred to the statutory works council. Additionally, a union's right to conclude a collective agreement was tied to the results of works council elections. This horizontal dual system resulted in the duplication of employee representation at workplace level and facilitated manoeuvring possibilities for management to play these two local in-

1 Originally, seven self-proclaimed national trade union confederations were invited, but one was later ejected due to an alleged relationship with the extreme right. 
stitutions against each other and to question the legitimacy of unions. This regulation also proved to be a union busting tool, especially in the case of newly-established unions in the context of anti-union managements (Tóth, 1997a).

Union participation in grievance procedures at workplace level and in the case of a disagreement between a worker and the employer was ended. The worker in question was able to sue the employer in a labour court but was not allowed to have a union or worker-initiated statutory internal grievance procedure taking place ahead of the legal process. This regulation effectively precluded unions from being able to represent employees in individual grievances (Tóth, 1998). This regulation made unions dependent on their bargaining power and/or management goodwill, and did not provide the organisational space for unions to act as an intermediary between employees and employer. The only meaningful statutory role for unions was to participate in the regulation of the terms and conditions of employment in the collective bargaining process (Tóth, 2005b).

The extension procedure for sectoral level collective agreements was made so complicated that practically only a handful of agreements have been so extended since the transition (Tóth, 1997b).

Even so, workplace unions which sought compromise with management may be able to achieve voice and informal bargaining power over individual and group-related issues, especially in companies where management welcomed unions and intended to introduce employment models based on worker commitment in order to ensure that management targets were met. Unions were also able to ensure especially strong positions in public utility companies, especially in state-owned public utility companies, where management sought the avoidance of conflict and ensured good conditions for unions.

To the detriment of unions and bipartite industrial relations, macroeconomic conditions in Hungary have not facilitated the maintenance of union membership levels. In contrast, the large-scale collapse and re-organisation of former state socialist companies, as well as the emergence of mass unemployment, has undermined union presence, membership levels and bargaining power. Between 1990 and 1993, union membership shrunk from four million to 1.5 million. Subsequently, unions have continued to lose members. Before the crisis, there were around half a million union members scattered across the six national confederations. The latest figures indicate that there are about 400 thousand union members. The number and coverage of workplace collective agreements has fallen, while sectoral collective agreements have not had any meaningful role in regulating the terms and conditions of employment (Tóth, 1997b).

At the same time, employer associations have functioned as voluntary associations of their member companies. Typically, they only represent a smaller circle of companies, although normally these are the most important ones in their respective areas of representation. They primarily function as the lobbying and business service agents of their members. The industrial relations activity of the employer associations is, practically speaking, taken up with little more than playing their part in the national and sectoral social dialogue machinery and, within these forums, participating in consultation processes over the planned regulations of government authorities. However, they 
do also occasionally provide non-mandatory recommendations to member companies on certain issues related to industrial relations (Tóth, 2005).

The consequence of these processes is that a top-heavy national industrial relations system has developed, in which the most important activity of the social actors is their participation in the state-sponsored machinery of social dialogue. The legitimacy and the resources provided by participating in this machinery has ensured for each organisation a legitimacy as well as organisational existence and revenue in spite of the low or dwindling membership levels. Even more, it has created the conditions for survival of all the six union confederations, despite the membership levels and the lack of meaningful resources for effective work.

It seems that the benevolent state-sponsored machinery has ensured voice, legitimacy and revenue regardless of the slow decomposition of the bipartite industrial relations system at workplace level. Attempts to create a unified union movement to pool resources for more effective work have been aborted. Indeed, political differences between the unions, and their different political ties to left and right, have played a key role in the abortion of these attempts. However, none of the union leaders had any interest in putting resources into a stronger unified organisation at the price of conceding a leadership position. At the same time, participation in the national tripartite system has provided sufficient revenue and legitimacy for each trade union to be able to maintain the image of a national-level confederation, despite certain confederations not having more than a few thousand, or a few tens of thousand, members and a handful of full-time employees.

\section{The polarisation of political life and its impact on the industrial relations system}

It was described above that the most important characteristic of the post-socialist industrial relations system was that it has increasingly shifted towards being a statesponsored industrial relations system. Its actors and institutions have become increasingly dependent on state support over the years as the political economic and societal transformation has proceeded in post-socialist Hungary and as their presence in the real economy, especially that of trade unions, has dwindled or has anyway been at a low level.

At the same time, growing political polarisation (Körösényi, 2012) undermined the political consensus concerning the basic institutional set up of the post-socialist democratic system, including that of industrial relations. This was so not only among the key political parties, but also among the industrial relations actors. Such a consensus had certainly existed in the early nineties: the key institutions of the social dialogue machinery and the new Labour Code, which provided the rulebook for the world of work, were created by a coalition government of moderate Christian conservative parties but were accepted by practically all major parties and industrial relations actors.

In 1994, the elections were won by a coalition of the left-wing MSZP and the liberal SZDSZ. At the same time, MDF, the dominant right-wing party of the transition period, disintegrated and lost much of its popular support. In the mid-nineties, FIDESZ, led by the charismatic and energetic Viktor Orbán, emerged as the leading party of the right. FIDESZ, which was originally a party of radical liberal youth, represented a generation change and offered a profoundly dynamic, modern, media-oriented and radical anti- 
communist alternative to the more traditional right-wing parties. On the other hand, FIDESZ embraced traditional Christian conservatism combined with a nationalistic tone which appealed to more traditional voters, especially in rural areas.

The cleavage between left and right became the key cleavage in Hungarian politics with the emergence of MSZP, which was the reformed and democratised former communist party, and FIDESZ, a staunch anti-communist party, as the leading forces in any potential left- or right-wing governing coalitions.

Given that the relationship to the former communist system became the major dividing line, a very strong emotional factor increasingly dominated the attachment to left or right: who or, in lack of personal experience, whose families had suffered more from the pre-1945 authoritarian or fascist regimes, and/or had enjoyed advancement during the communist regime, especially during the seventies and eighties, which were the golden years of Hungarian socialism under the leadership of the moderate and paternalistic János Kádár, or had suffered more from the brutal and partisan communist regime. This cleavage was reinforced with MSZP making an alliance with the liberal SZDSZ. SZDSZ was, to many on the extreme right and to ultra-nationalist forces, considered as a neo-liberal Jewish party and as a comprador force of the global financial elites which was selling the country to foreign capital (Tóth and Grajczjár, 2009). In response, SZDSZ claimed that the right had the tendency of associating with the forces and slogans of fascism and tried to forge a non-modern alliance against markets and modernisation.

Thus, the left-liberal block occupied a modern, globalisation and pro-European position, while FIDESZ increasingly shifted away from the liberal conservative, proEuropean position of MDF to embrace a more ambiguous position, which called for national solutions with somewhat nuanced euro-pessimism and a critical view of globalisation.

The consequence of these emotionally-ridden suspicions, hatred and fear on both sides of the cleavage was the development of a kind of tribal politics, ${ }^{2}$ in which each political tribe saw an enemy tribe in the other. No wonder that the Hungarian political science discovered and applied the notion of 'pillars' from the Dutch literature (Enyedi, 1993). This emotionally-laden tribal politics, fuelled by suspicion, hatred and fear of the other, increasingly turned Hungarian political life into a cold war between right and left (Tölgyessy, 2013; Kis, 2013): a cold war, in which any, or almost any, means were allowed to win over, to gain political power or to retain it, irrespective of long-term rationality, sustainability or ethical considerations.

This changing political landscape had an enormous influence on the functioning of the industrial relations system and on the actors, especially on the position and politics of political parties and trade unions. MSZP became a major supporter of the institution of statutory tripartite social dialogue and, in this respect, of being a good citizen of social Europe. FIDESZ, on the other hand, turned against such a neo-corporatist style of arrangement (Öry, 1998). The key issue, however, beyond the ideological differences, was the relationship towards the unions. MSZP and the former communist unions had tacit and/or open ties to each other, while FIDESZ had developed a deep suspicion

2 Expression borrowed from Tamás (1999), but see also : Varga (2005). 
towards the former communist unions, claiming that they were representing the same shadow power of the former communist elite in a disguised form (Thoma, 2004).

The MSZP-dominated government between 1994 and 1998, by and large, strengthened the framework which had been created in the early nineties. Nonetheless, it slightly changed the balance since the government went on to reinforce the position of the trade unions. One of the key reasons for this shift of balance was that, within the unions, the former communist unions held the dominant position, especially MSZOSZ, which was an open supporter of MSZP. Approaching the 1998 elections, therefore, the government initiated moves to change the balance of power among the union confederations by reconfiguring voting rights on the employee side of the tripartite body to benefit the larger, former communist unions, especially MSZOSZ, at the expense of the smaller ones, among them the former anti-communist unions, Liga and Munkástanácsok.

A FIDESZ-led right-wing coalition won the 1998 elections. FIDESZ scrapped the previous government initiative to change the balance of the formal positions among the unions. More importantly, FIDESZ wanted to repel the neo-corporatist tripartite machinery and thus reduce the influence of unions on national politics. The government therefore disbanded the national tripartite body and set up two parallel bodies with a somewhat diminished importance and portfolio. It also ended the tripartite governance of the national healthcare and pensions funds (Tóth, 2002).

These measures met with the disapproval of the trade unions. MSZP promised to re-establish the national tripartite body and also that it would negotiate with the social partners with a view to reaching agreement in the new body. Some unions, especially those belonging to MSZOSZ, openly supported MSZP in the 2002 election process. Union activists participated in the campaign on behalf of MSZP and their demands were incorporated into the MSZP programme.

The 2002 elections were won by MSZP in coalition with the liberal SZDSZ. The tripartite body was re-established, modifications to the Labour Code reinforced unions' rights and greater entitlements were legislated at workplace level. The key economic demands of the unions were implemented by the government.

The 2006 elections were again won by the MSZP-SZDSZ coalition, which made populist promises of ever-increasing growth. Nevertheless, after the 2006 elections a deep economic, political and ethical crisis broke out, the result of which was the disintegration of the key underpinnings of the post-socialist industrial relations. The crisis was caused by the build up of debt between 2001 and 2006. The emergence of the crisis, however, was provoked by the demands of the EU to meet the conditions of the European Stability Pact, which required the initiation of a new government policy focused on strict economic policy and de-leveraging. After winning the elections, the government was forced to make a U-turn and to initiate an austerity package which led to recession. The economic and political crisis was deepened by the leaking of a secret speech of the Prime Minister to MSZP MPs, in which he admitted that he had lied during the elections campaign and had not governed properly.

Huge anger broke out across the country against MSZP, and FIDESZ demanded a new set of fair elections. The government did not step down, but embarked on a series of neo-liberal style reforms alongside the austerity measures. FIDESZ opposed any neo-liberal reform and orchestrated popular resistance against the government which 
included mass rallies, the collection of protest signatures and a referendum, which was won by a landslide, against the key neo-liberal reform measures. In these heady days of resistance against the neo-liberal reforms, FIDESZ portrayed itself as a plebeian party, which fought for the welfare state against the corrupt and oligarchic circles of the past who would sell the country to foreigners.

The reconfiguration of the political landscape in the wake of the dramatic events of 2006-2009, realigned party and trade union ties across the board. Trade unions, even the former communist ones, protested against the austerity measures and the attempts at neo-liberal reforms. The relationship between MSZP and the unions weakened to being almost non-existent. Even so, there was a difference in the boldness of the protest. MSZOSZ and, typically, the other former communist unions primarily expressed their disagreement in the tripartite body and organised only a few demonstrations against the government measures, attracting little more than several hundred participants. On the other hand, Liga and Munkástanácsok, which had developed close ties with FIDESZ, organised national strike actions to force the government to withdraw the neoliberal reforms. No more than twenty-thirty thousand employees participated in these actions, but Liga managed to halt the national railway company, which augmented the impact of the strike way beyond the number of its participants.

These strikes contributed to the withdrawal of the neo-liberal reforms. Meanwhile, the spectacular and successful strike actions enhanced the legitimacy of Liga and a number of unions joined it. Reportedly, Liga became one of the biggest unions and its leader has become one of the most well-known union leaders in the country.

The changes and events between 2006 and 2010 prepared the ground for the onslaught of FIDESZ on the post-socialist industrial relations system subsequent to the 2010 elections. The U-turn, the ethical consequences of the leaked speech, the unsuccessful neo-liberal reforms and the recession devastated MSZP, which had been the key political force in maintaining the social dialogue machinery, the key institution of the post-socialist industrial relations system.

Meanwhile, the bleeding of union membership gained new impetus in the wake of the economic crisis. There took place a re-configuration of power relationships among the union confederations, Liga becoming one of the largest union confederations, almost on an equal footing with the former major union confederations. Even more important was that it proved to be the only major organisation which was able to implement important protest actions against unpopular reforms. During this period, the political ties between Liga and FIDESZ further developed, whereas the relationship of MSZP with the unions mostly disintegrated.

\section{The destruction of the post-socialist industrial relations system}

The 2010 elections were won by FIDESZ, which gained two-thirds of the parliamentary seats. The importance of this landslide victory was that it secured for FIDESZ a super-majority carrying an entitlement even to change the Constitution and, consequently, any constitutional institution. FIDESZ interpreted this landslide victory as a revolution and claimed it had received a mandate to re-organise the country and overcome the heritage of the last twenty years; to recast the wrong model of the transition. 
This overarching programme included the system of industrial relations. The reorganisation had six major facets:

- recasting the national level social dialogue

- changes in the strike law and the labour law

- recasting interest representation in public administration, the armed forces and in some public services

- shift towards face-to-face consultation with selected partners

- boosting the standing of those trade unions close to FIDESZ

- nudging the disintegration of unions not close to FIDESZ.

\section{Recasting the national-level social dialogue}

The national tripartite social dialogue body was dissolved. It was re-established as a new consultation forum only for social actors in the competitive sphere of the economy, including industry and business services. Accordingly, only three employer associations and three trade union confederations - Liga, Munkástanácsok and MSZOSZ, the only former communist union confederation - were invited to this new forum. State support for the participants was also reduced. The new forum is no longer a body which meets regularly, discussing all major issues related to the world of work, but a body which is irregularly convened when the government has an issue it wants to discuss with the social partners. This move ended the former media power of the unions, the source for which was the widely-reported discussions in the statutory tripartite body.

The re-organisation also closed the door to access to the national level social dialogue as regards unions in public utility companies, mostly represented by Autonómok, and those in public administration and public service, mostly represented by SZEF and ÉSZT.

\section{Changes in the strike law and the labour law}

An amendment of the strike law has made it practically impossible for unions in public utility companies to call a strike. This measure ended the strike power of the public utility unions, which had paralysing effects in the past.

Parliament legislated for a new Labour Code, which has dramatically weakened the positions of unions at workplace level in two ways. Firstly, the new Code changed the earlier balance of rights between employee and employer. The new Code, clearly favouring the employer side, made labour contracts more flexible and granted greater legal options to employers to terminate labour contracts at will. At a time of crisis and unemployment, this change has clearly weakened the position of employees at the workplace vis-à-vis their employers. Secondly, the Labour Code heavily curtailed the rights and entitlements of unions at workplace level. These new rules are most likely to undermine the financial and organisational stability of most unions, except where employers grant greater resources to unions. However, the law prohibits employers from providing better conditions, above the minimum level set by the law for unions in publicly-owned workplaces. This change also weakens the position of trade unions, especially if an employer does not want to deal with an independent employee interest representation organisation (Tóth, 2012). 
Recasting interest representation in public administration, the armed forces and in some public services

The government has re-cast interest representation to make sure that unions in public administration, the armed forces and in some public services would not represent an alternative force to the will of the government.

Parliament has legislated for the creation of the Hungarian Chamber for Employees in the Armed Forces. This Chamber is intended to be the statutory professional and interest representation body for employees in the armed forces, with mandatory automatic membership for all categories of employees listed in the law. The Chamber must be consulted and informed concerning issues on employment-related issues of employees in the armed forces. The law also stipulates that the Chamber be granted the right to create an Ethical Rulebook for employees and should have the right to adjudicate on whether or not a member has infringed the Ethical Rulebook. In cases of infringement, the Chamber shall initiate a grievance procedure. The Chamber is also intended to represent employees in consultative forums in the armed forces dealing with the terms and conditions of employees. ${ }^{3}$

A similar chamber has been created for teachers in public education.

Unions called in vain that the government's regulation of the chambers was an infringement of the legal rights provided to trade unions ${ }^{4}$ and protested against their creation and the cutting of union rights. ${ }^{5}$ It is of little comfort to unions that, on elections for the presidencies of the Chambers, the unions gained some level of representation, which ensures them some stability and voice. ${ }^{6}$

It has further weakened unions in the armed forces that the government has ended the traditional check-off system for the payment for membership fees. This measure led to a drop in membership of one-half and undermined the financial situation of unions. One union leader has pointed out that the intention of the government was to make independent interest representation by unions non-existent. ${ }^{7}$ Also ended was the practice of the provision of free office space and telecommunications services. Additionally, the new Labour Code changed the practice of the accounting of leave for union purposes; thus, unions no longer receive financial compensation for unused statutory leave.

3 1996. évi XLIII. törvény a fegyveres szervek hivatásos állományú tagjainak szolgálati viszonyáról (a Magyar Rendvédelmi Karra vonatkozó kivonat) http://www.rve.hu/attachments/article/1782/MRK Hszt.pdf.

4 BRDSZ ‘A szakszervezeti jogokkal ütköző rendelkezések a Magyar Rendvédelmi Kar szabályozásában' available at: http://www.brdsz.hu/html/main/2012/szakszervezet_vs_kar.pdf.

5 Edupress (2013) 'Több szakszervezet tiltakozik a pedagógusi kar létrehozása ellen' 13 May, available at: http://www.edupress.hu/hirek/index.php?pid=egycikk\&HirID=29115; Liganet (2012) ‘Sikerek a rendvéldelmi kar választásokon' available at:

http://www.liganet.hu/page/88/art/6583/akt/1/html/sikerek-a-rendvedelmi-kar-valasztason.html.

6 Liganet (2012) ibid.

7 'Bárdos Judit: a béreket három évre előre ismét befagyasztották' Népszava Különszám 1 May 2013, available at: http://www.brdsz.hu/index.php/8-altalanos-hirek/318-bardos-judit-abereket-harom-evre-elore-ismet-befagyasztottak. 
This change, together with the drop in membership due to the unfavourable environment has, in practice, resulted in such a severe drop in revenues that most unions can no longer afford to have full-time union officers in the public sector. Smaller unions are relying on voluntary work and the voluntarism of retired former union officials. ${ }^{8}$

\section{Shift towards face-to-face consultation with selected partners}

There has also been a shift towards face-to-face negotiations with selected partners, especially with employer organisations and certain unions, most notably Liga and Munkástanácsok, over selected issues instead of using the bodies of social dialogue for consultation with a view to reaching agreements with all the social partners. This practice can be seen in detail in the case of consultations over the draft of the new Labour Code (Tóth, 2012).

\section{Boosting the standing of those trade unions close to FIDESZ}

This new selective policy was made clear during the consultation period on the new Labour Code, in which Liga was the main negotiating partner of the government. Only MSZOSZ among the former communist unions was invited to have some role in the institutional framework. However, the real partners for the government are those unions, Liga and Munkástanácsok, which were the anti-communist pro-democratic unions in the period of the transition and which fought together with FIDESZ against the neo-liberal austerity measures of the MSZP-SZDSZ coalition between 2006 and 2010. Liga also received, together with one employer association, a major government grant for the purposes of ensuring capacity building for social dialogue. ${ }^{9}$

According to the accusations of the President of Autonómok, Liga is buying support by offering various benefits for workplace and higher-level unions to join Liga. ${ }^{10}$

\section{Nudging the disintegration of unions not close to FIDESZ}

The new government has sidelined public sector unions and effectively ended the social dialogue forums available for them to make their voice heard. The public utility

8 'Egységes érdekképviseletet kellene létrehozniuk a szakszervezeteknek a közszférában?' Népszabadság 16 August 2012, available at: http://www.szakszervezetek.hu/index.php/ hirek/1546-egyseges-erdekkepviselet-kell-letrehozniuk-a-szakszervezeteknek-a-koezszferaban [last accessed 16 June 2013]; 'Emlékeztető az MKKSZ 2012.december 4-6 között tartott kibővített elnökségi és vezetői értekezletéröl' 14 December 2012, available at: http:// www.mkksz.org.hu/index.php/hirek-ujdonsagok/68-emlekezteto-az-mkksz-2012-december-4-6-kozott-tartott-kibovitett-elnoksegi-es-vezetoi-ertekezleterol [last accessed 16 June 2013].

9 'Már csak a Liga nyerheti a másfél milliárdos támogatást' Népszabadság Online, 18 March 2013, available at: http://nol.hu/archivum/20130318-mar_csak_a liga_nyerheti_a_masfel_milliardos_tamogatast?ref=sso [last accessed 15 June 2013].

10 'Folyik a helyezkedés a szakszervezeteknél' Népszabadság Online, 4 June 2013, available at:

http://nol.hu/belfold/folyik_a helyezkedes_a_szakszervezeteknel [last accessed 15 June 2013]. 
unions lost their bargaining chip in the strike power they had in public utility companies as a result of the amendment of the strike law. These two measures practically sidelined SZEF and Autonomók, the two national confederations which mostly organised employees in the public sector and in the public utility sector, respectively.

Up to now, there have been few attempts effectively to counter the re-organisation efforts of the government. Protests and demonstrations have had no real effect on government policies. It is also important to note that protesting unions have not been able to put real pressure on the government by mobilising huge protest actions. A weak and divided organisational structure, low membership levels and a lack of a culture of mobilising employees have certainly contributed to the weaknesses of these protest actions. Years of reliance on top-level negotiations and informal lobbying have undermined unions' power to mobilise.

The most recent news is that the presidents of the three major former communist unions, MSZOSZ, SZEF and Autonómok, have agreed that they will pool resources and form a new amalgamated unitary confederation in the autumn of 2013. However, the details are still not known as to how this amalgamation will take place and what political position will be occupied by the new confederation when it is established. Nonetheless, these three unions represent about two-thirds of Hungary's 400000 union members. If they really will amalgamate to form a new joint unitary confederation, this may represent a chance to arrest decline and disorganisation among the left-wing oriented union bloc.

\section{Conclusion}

The post-socialist model, alongside the weakening of its base among the social partners, especially that of the unions, became increasingly dependent on the goodwill of the state. The national and sectoral level social partners - trade unions and employer associations alike - became increasingly dependent on the revenue provided by the state through various channels as well as on the lobbying space ensured by the social dialogue machinery at national and sectoral level. However, they maintained a certain amount of autonomy and had also independent resources, which enabled autonomous policy-making and ensured room for real negotiations on certain issues.

At the same time, the post-socialist industrial relations system, centred as it was on a top-heavy national level social dialogue, contributed to the weakening of the bipartite industrial relations system. Participation in the national tripartite machinery shifted both unions and employer associations to concentrate their efforts on making their voices heard on national level issues and to achieve measures which were favourable to them via lobbying and political pressure. Such national level lobbying activity consumed much of their resources and certainly diverted their attention away from realworld organisational and interest representation issues at lower levels. This led to a weakening of autonomous bipartite industrial relations at workplace level. The lack of autonomous bargaining, one half of a vicious circle, then reinforced a belief in the state and that the role of the social actors was to influence state regulation to ensure the interests of their members. 
There thus developed a form of interest representation in the clouds on national issues, while employee-employer interaction increasingly became a face-to-face bargain without containing an intermediation role for interest representation organisations.

This state-centred and state-sponsored model facilitated the attempt of the Orbán government to establish a new system, a state-dominated system, in which the state is re-designing the institutions and rules and facilitating the consolidation of friendly actors in order to ensure omnipotent government. ${ }^{11}$ Trade unions, whose real influence and power was dependent on a benevolent state, were unable to mount any serious challenge to it once it had turned less benign. Moreover, political divisions in the union movement have ensured that there were unions which have benefited from the new turn. These unions have provided a legitimacy to the government measures due to their tacit, or open, political commitment to right-wing parties. On the other hand, those unions which have been disadvantaged by the policy turn could not effectively counter the government due to their organisational weaknesses and also due to the disintegration and legitimacy problems of the left in the wake of the disastrous years of 2006-2010.

The six measures listed above amount to putting an end to the post-socialist industrial relations system, centred on national level social dialogue with the participation of traditional partners which are considered to be national actors. They signal, in its place, the beginning of a new era, one of state-dominated industrial relations. In this era, the state has effectively pushed unions out from the armed services and from some public sectors, undermined union bargaining power in public utility companies and weakened non-friendly unions.

This represents the second attempt of FIDESZ to change the rules of the game in the world of the work. Between 1998 and 2002, when it first governed the country, it initiated similar measures - albeit in a less bold and resolute form and without seeking alliances among union confederations. I argued at the time that the effect of the government measures would be the disintegration of the post-socialist industrial relations system (Tóth, 2002). Nonetheless, FIDESZ's electoral defeat in 2002 turned the tables, and the returning MSZP-dominated government practically re-established most of the key elements of the institutional system and reinforced the positions of the unions.

This time, however, FIDESZ has learned its lessons and introduced a much bolder and more resolute reform. This time, the unions are clearly divided. The government only has to deal with the open opposition of a few union confederations while others, tacitly or openly, support the creation of a state-dominated system. Additionally, unions are much weaker and their positions have been thoroughly undermined in key sectors of the economy.

The electoral defeat of the current government may influence the shift towards a state-dominated industrial relations system in 2014, although the prospects for such a change seems to be unlikely at the moment. However, government change alone is not sufficient. It would be difficult to re-establish the former system, centred on a national level tripartite system, given the disintegration of the social partners and especially that of trade unions over the years of economic crisis and a non-supportive political envi- 
ronment. It would be little more than an illusionary corporatism without real foundation. ${ }^{12}$

The key for renewal is to develop a new bipartite framework, operational at workplace and possibly at sectoral level, which more effectively facilitates the creation of an autonomous bipartite industrial relations system based on effective regulation. This would help arrest state dominance of the work of world and, at the same time, ensure that there could be developed, through joint regulation, a more flexible and competitive - and simultaneously more fair - system for everybody.

\section{References}

Bruszt, László (1993) 'Gondolatok a gazdasági kapcsolatok rendszeréröl’ Társadalmi Szemle 2: 35-45.

Enyedi, Zs (1993) 'Pillér és szubkultúra. A politikai-kulturális tagolódás egy lehetséges fogalmi kerete' Politikatudományi Szemle 2(4): 21-55.

Héthy, Lajos (1995) 'Anatomy of a tripartite experiment: Attempted social and economic agreement in Hungary’ International Labour Review 134(3): 361-376.

Kis, J (2013) 'Az összerlódott idő' Beszélő 5 May, available at: http://beszelo.c3.hu/ onlinecikk/az-osszetorlodott-ido-\%E2 \%80\%93-masodik-nekirugaszkodas [last accessed 15 June 2013].

Kollonay, Cs and M. Ladó (1996) 'Hungary' in U. Carabelli and S. Sciarra (Eds.) New Patterns of Collective Labour Law in Central Europe. Czech and Slovak Republics, Hungary, Poland Giuffre Editore: Milano, pp. 101-161.

Körösényi, András (2012) ‘A politikai polarizáció és következményei a demokratikus elszámoltathatóságra’ in: Boda Zsolt and András Körösényi (Eds.) Van irány? Trendek a magyar politikában MTA TK Politikatudományi Intézet - Új Mandátum Könyvkiadó: Budapest, pp. 284-309.

Ladó, M (1997) A munka világával összefüggő érdekegyeztetés országos intézményei Munkaügyi Minisztérium.

Mises, L (1944) Omnipotent Government: The Rise of the Total State and Total War, Yale University Press.

Ost, D (2000) 'Illusory Corporatism in Eastern Europe: Neoliberal Tripartism and Postcommunist Class Identities' Politics \& Society 28(4): 503-530.

Öry, Cs (1998) ‘A munka hadának’ in: Kiadó Kairosz Janus-arcú rendszerváltozás. Tanulmányok pp. 272-284.

Stark, D and L. Bruszt (1998) Postsocialist Pathways. Transforming Politics and Property in East Central Europe Cambridge: Cambridge University Press.

Tamás, Gáspár Miklós (1999) Törzsi fogalmak I-II Atlantisz: Budapest. 
Thoma, L. (2004) 'A baloldal dilemmája: a szakszervezet' Mozgó Világ 28. Évf. 1, available at: http://epa.oszk.hu/01300/01326/00025/janu15.htm [last accessed 15 June 2013].

Tóth, A (1997a) 'The Invention of Works Councils in Hungary' European Journal of Industrial Relations 3(2): 161-181.

Tóth, A (1997b) 'The role of multi-employer collective agreements in regulating terms and conditions of employment in Hungary' Transfer-European Review of Labour and Research 3(2): 329-356.

Tóth, A (1998) 'Legal Regulations and Reality: Changes in Legal Regulations and its Impact on Industrial Relations' in J. Schramm (Ed.) Arbeitsrecht und Arbeitswirklichkeit in den MOE-Staaten. Deutsche Gesellschaft für die Vereinten Nationen Berlin: Freie Universitat Berlin, DGVN Landesverband, pp. 63-87.

Tóth, A (2002) 'The Failure of Socialdemocratisation of the Hungarian Union Movement' in S. Crowley and D. Ost (Eds.) Workers after Workers' States New York, Oxford: Rowman and Littlefield, pp. 47-71.

Tóth, A (2005a) 'A munkáltatói szövetségek helyzete és szerepük a munka világában' in K. Fazekas and J. Koltay (Eds.) Munkaerőpiaci Tükör 2005 MTA Közgazdaságtudományi Intézet - Országos Foglalkoztatási Közalapítvány, pp. 12-31.

Tóth, A (2005b) 'Szabályozott foglalkoztatás vagy szabályozottabb egyéni alku? A posztcéhes posztszocialista szakszervezetek eltérő stratégiái a munkaviszony szabályozására’ in: K. Fazekas and J. Koltay (Eds.) Munkaerőpiaci Tükör 2005 MTA Közgazdaságtudományi Intézet - Országos Foglalkoztatási Közalapítvány, pp. 124-135.

Tóth, A (2012) The New Hungarian Labour Code - Background, Conflicts, Compromises available at:

http://www.fesbp.hu/common/pdf/Nachrichten_aus_Ungarn_june_2012.pdf [last accessed 15 June 2013].

Tóth, A and I. Grajczjár (2009) 'Miért olyan sikeresek a radikális nemzeti-populista pártok nagy társadalmi-gazdasági átalakulások, vagy válságok idején?’ Politikatudományi Szemle 28(3): 7-32.

Tölgyessy, P (2013) A Fidesz rendszer természete, kézirat MTA TK Politikatudományi Intézet - Új Mandátum Könyvkiadó: Budapest.

Varga, D. G (2005) A törzsi háború természetrajza - a rendszerváltozás Magyarországán LKD kiadó. 